Article

\title{
Scenarios of Sustainable Fishing in the Zapatosa Marsh (Colombia) Simulated with a System Dynamics Model
}

\author{
Andres Camilo Castaño-Barreto ${ }^{1, *}$, Carlos Alberto Jaramillo-Cruz ${ }^{1}$, \\ Raul Andres Molina Benavides ${ }^{2}\left(\mathbb{C}\right.$ and Alberto Stanislao Atzori ${ }^{3}$ \\ 1 Grupo de investigación “ICTIAP” Ciencia, tecnología e Innovación en Acuicultura y Pesca, Facultad de \\ Ciencias Agropecuarias, Universidad Nacional de Colombia, Palmira 763537, Colombia; \\ cajaramillocr@unal.edu.co \\ 2 Grupo de investigación “Conservación, Mejoramiento y Utilización del Ganado Criollo Hartón del Valle y \\ otros Recursos Genéticos Animales en el Sur-Occidente colombiano", Universidad Nacional de Colombia, \\ Palmira 763531, Colombia; ramolinab@unal.edu.co \\ 3 Section of Animal Science, Department of Agriculture, Università degli Studi di Sassari, 07100 Sassari, Italy; \\ asatzori@uniss.it \\ * Correspondence: accastanob@unal.edu.co; Tel.: +57-3154122119
}

Received: 20 February 2020; Accepted: 12 April 2020; Published: 23 April 2020

\begin{abstract}
The Zapatosa marsh (ciénaga de la Zapatosa) is located in the Department of Cesar in Colombia. In 2018, the muddy complex of Zapatosa was declared a Ramsar wetland, for this reason, it is necessary to develop management strategies for the marsh that allow not only the conservation of the ecosystem. The objective of this work is to use System Dynamics as an evaluation tool for three possible management scenarios of artisanal fishing in the Zapatosa marsh. A qualitative causal diagram and a quantitative Stock and Flow diagrams were designed to describe the dynamics of fish and fishermen populations in the marsh. The initial model setting and parametrization derived from values gathered from different sources of information. The calibration of the model was carried out with reference data on total catch of kilograms of fish and population data from the Department of Cesar. The data obtained through the "Aquaculture and artisanal fisheries survey of the Department of El Cesar" in 2018 were reproduced in the model and then compared with 3 alternative management scenarios. Scenario 1 included strictly applying of the fishing stopover for the species Prochilodus magdalenae and for catfish (Pseudoplatystoma magdaleniatum, Pimelodus blochii y Sorubim cuspicaudus). Scenario 2 considered to apply the same prohibitions, but with a payment to fishermen for the care of the swamp at the time of prohibition. In Scenario 3 the fishermen under fishing stop will receive an income of a legal Colombian minimum monthly salary and will be engaged in practices of ecosystem services. Results showed that in some scenarios the economic situation of the fishermen is unable to meet the monthly family expenses in different periods of the year. On the other hand, there is greater economic stability and fish populations when adopting Scenario 3, but it is difficult to achieve in the short or medium term. Scenario 2 shows little recoveries in fish populations and a higher money availability to the local community than in Scenario 3, in certain months, presenting the best short-term management option. The presented model encourages further simulation scenarios of the Zapatosa Marsh.
\end{abstract}

Keywords: ramsar wetland; fisheries management; simulation modeling 


\section{Introduction}

\section{System Dynamics in Fisheries and Fishing Systems}

The phenomenon of overfishing has been noticed in the Magdalena basin for several years and the area is characterized for evidences of overfishing. In 1973, catches were around 79,000 tons, seven years later they dropped to 65,000 tons, and in 2006 they barely reached 6000 tons, when under normal conditions catches could reach 20,000 tons [1]. Fluvial fishing in Colombia has always been based on migratory species that in general includes among others bream, striped catfish and the endemic specie of Prochilodus magdalenae (named bocachico in the region) [2]. These species go up the river and return to the marsh producing the phenomena of oscillating patterns of population dynamics which strongly affect fishing catch which are locally called periods of "high catch" (subienda), "low catch" (bajanza) and "mid catch" (mitaca) [1]. The Spanish terms subienda, bajanza and mitaca are local terms referring to the complex phenomena that indicated both to the hydrological changes in the marsh and the variation in catching opportunity due to the seasonal fish abundance.

The National Aquaculture and Fisheries Authority (AUNAP) reports for 2018 a total of 2533 fishermen for the Department of Cesar [3]. Rangel [4] reports that only for the municipality of Chimichagua there are about 3500 fishermen, organized in 6 associations and having 325 canoes [4]. Similarly, in the Third National Agricultural Census of Colombia carried out by DANE in 2013-2014, reports that in the Department of Cesar there are 310 fishing productive units. Inconsistencies in the number of artisanal fishermen for the department have to be attributed to several factors depending on the period of the year on which census are carried out and on the abundance of fish in the marsh which seems to strongly affect the number of fishermen. It is also clear that the social conditions of the fishermen are critical and variable. A census conducted by CORMAGDALENA estimates that $20 \%$ of the fishermen are illiterate [5]. Similarly, INPA (2002) cited by Viloria de la Hoz [6] calculated the average income of a fisherman, which at that time was close to the minimum remuneration, was around 319,000 Colombian pesos per month equal about 100 dollars [6]. The main problem is that the fishing catch is not constant but is seasonal and thus incomes of these communities are variable throughout the year, especially depending on the climatic conditions in the marsh. This situation also causes indebtedness of the fishermen during part of the year. In particular fishermen are obliged to sell the fish to marketer who lends them money, eliminating their possibilities of economic growth [6].

The muddy complex has more than 500 vascular plants, 45 species of fish, 30 species of mammals, and hundreds of migratory birds from Canada [7]. This biodiversity has been affected, in the last 50 years the system has suffered transformations, due to the increase in the demographic rate, which in turn increased: the use of the flooded areas, the extensive cattle ranching, crop and plantations and the practice of subsistence fishing. The new management colonized the swampy areas and turned them into private properties, also suppressing the traditional cultivation and leaving a large part of the population within the swamp, relying their subsistence to the resources of the swampy area [8].

It highlights the need to understand the dynamics and structure of the artisanal bioeconomic fishing system of the Zapatosa marsh in the Department of Cesar. This swampy area was also added to the new category of conservation as Rampsar Wetland in 2018, to stimulate the development of valuable and sustainable elements of managing and diversifying the artisanal fishing activity in this swampy system.

Systems Dynamics methodology target the hidden core structure driving the behavior of the system [9-11]. Drawing causal maps or CLD by using System Thinking (ST) and System Dynamics (SD) approaches, is a technique for mapping the existence of the feedback within and across interacting subsystems. The modelling process demands the identification and definition of problems, the overall system conceptualization and the qualitative modelling, which often impact our initial system understanding. ST and SD can support designing better policies working on the systems structure both enhancing insights elicitation and increasing the stimulus to performing accurate policy discussion and evaluation [12]. Through the CLD, an explicit understanding of the problem can be generated, 
identifying the relationships between the components of the structure, especially the biotic and socioeconomic aspects. Quantitative modelling can be achieved translating the CLD in Stock and Flow diagram (a representation of the system under the hydraulic metaphor) which describes the math of the system over time using a set of differential equations. It allows to simulate short and long term scenarios of the system behavior and formulate and test possible policies of the system management.

Precisely a simple model of fisheries has been presented in the book of Meadows [11] resembling the fishing system similar to the prey-predator model, consisting of two renewable stocks [11]. The predator is represented by a group of fishermen in a lake whereas its prey is the fish. The system could be also characterized by a given carrying capacity of the lake or lagoon. The biological equilibrium in this model will also be governed by the interaction between fish and fishermen, and the economic factors determining the increase or decrease of catch capacity.

Dudley [13] proposed, instead of a model with number of individuals, a model of fish population that combined fishing activities with fisheries management decision-making. The population component is based on the dynamic biomass model [13]. The same author argued that models targeting complex fishing problems in a transparent and understandable manner without focusing too much on the details of population dynamics are needed.

Different investigations have been carried out on fishing systems worldwide, generally of the maritime type and using system dynamics as a tool. At the Tucuruí dam in Brazil, Camargo \& Petrere [14] developed a dynamic model linking information gathered from fishermen and fish stocks, and then created scenarios where fishing pressure increased in order to foresee moments of conflict due to the scarcity of the fishing resource [14]. They took into account variables such as the amount of fishing, fishing zones, conflicts, water reserve systems and economic incomes. These variables were added to the model for a period of 10 years and the results indicated that hook fishing would be the most profitable and that possible conflicts may exist in the short term due to the scarcity of resources [14].

In Colombia, Fadul [15] developed a System Dynamics model of the sociobiological system of the Ciénaga Grande de Santa Marta to understand the dynamics of the most important variables describing artisanal fishing, and also considering the social and biological context in which it is developed. These authors observed the dynamics of the swamp under different policies and scenarios and stated that the restriction of juvenile immature fishing showed the best results in term of sustainability of fish and catches. This policy acted by enabling the conservation of the regenerative capacity of the resource. In addition, ensuring the conservation of fish also allows to achieve increases in fishing abundance throughout the year and increases of presence of individuals with high weight which also ensure coverage of their operating costs [15].

On the other hand, Garrity [16], used a system dynamics model for individual transferable fishing quota (ITQ) in the United States, in order to arrange the various ITQs of the total allowable catch (TAC) in the Bluefin tuna fishery. ITQ systems offer incentives for long-term management, but when fisheries are managed close to the biological limit, incentives are inadequate for rebuilding stocks [16]. Free market design means that fishermen may be in conflict with the long-term public sustainability objectives of fisheries management [16]. The authors propose an adaptive control scheme with a contingent public/private transfer to improve long-term outcomes for both the local community and the general public [16].

In 2015 in Portugal, system dynamics were used to simulate the behavior of the artisanal dredging fishery on the south coast of this country, including the four species and two main fleets. The two scenarios were simulated to assess the impact of the regulations on the sustainability system: Scenario 1 simulates the permanent reduction of fishing effort, Scenario 2 simulates the closure of a species for a period of one year to allow its recovery [17]. They found that the performance of fishing industries decreases in the year when the system cannot return to the average income levels of three years after closure [17]. Similarly, in Alaska, a dynamic model was used to study the red salmon fishing industry, where several scenarios were created with different management models that serve as the basis for 
making decisions regarding the fishing season and the most favorable methods for the fisherman and the ecosystem [18].

Storch, Glaser, Ye, \& Rosenberg [19] examined two types of models, which included single-species fishery stock assessment and multi-species marine ecosystem models [19]. The authors claim that both are efforts to predict the trajectories of stocks and ecosystems to inform fisheries management and conceptual understanding. However, many of these ecosystems exhibit nonlinear dynamics, which may not be represented in the models, this is how the model results can underestimate variability and overestimate stability [19]. Using nonlinear forecasting methods, they compared the predictability and nonlinearity of the model results, using data and models for the California Current System. Compared to model inputs, the time series of outputs processed by the model show more predictability, but a higher prevalence of linearity, suggesting that models misrepresent the actual predictability of modeled systems. Therefore, caution should be used in the use of such models for the management or exploration of scenarios, since it can produce unforeseen consequences, especially in the context of unknown future impacts [19].

In 2018 Inomata et al. [20] analyzed the proposal of an alternative model for the management of commercial fisheries in the Middle Black River region [20]. The model was developed using Stella ${ }^{\circledR 9} 9$, simulating two scenarios to investigate the dynamics of the fish population, in the first one they considered a reduction of the population replacement values to half of the initial values, a 50\% increase in fishing effort, and variable costs and monthly average prices for fish, and in the second they analyzed the effect of prohibiting commercial fishing. The planning horizon used was 120 months, given the results achieved by the simulations, it would be interesting for the authorities of the region to have effective control over access to fishing and that users are aware that these natural resources [20]. This type of study makes possible to identify the dynamics and variations of the fishing system in order to take appropriate measures for the preservation of ecosystems and the socio-economic stability of fishing communities [17].

The objective of this work was to evaluate three management scenarios of artisanal fisheries in the Zapatosa marsh in the Department of Cesar by using a system dynamics approach. A specific focus included the comparison of socioeconomic aspects of local inhabitants and the fish stocks in the marsh.

\section{Materials and Methods}

\subsection{Area of Study}

The Zapatosa marsh is part of a complex system of marshes formed by the confluence of the Cesar River with the Magdalena River (Figure 1). This complex was declared a Ramsar Wetland in April 2018, has an area of 123,624 hectares, with flood zones that vary according to the season and works as a buffer of the floods of the Magdalena River, its geographical coordinates are $9^{\circ} 05^{\prime} 30^{\prime \prime}$ north latitude and $73^{\circ} 49^{\prime} 44^{\prime \prime}$ west longitude [7]. It is located between the municipalities of El Banco (Magdalena) and 9 municipalities of the Department of Cesar; it covers the valley of the Cesar River, approximately 39\% of the territory, which is also where the main coal deposits are, likewise, the valley of the Magdalena River. It is an area with great advantages for development of agricultural activity as reported by the Regional Competitiveness Commission (CRC) in 2011 [21].

Of the nine municipalities in the Department of Cesar, including the Zapatosa marsh, only three have direct jurisdiction over the marsh water [6]. According to the 2005 General Census, trade and service activities concentrate about $80 \%$ of the economic gross margin of the municipalities of the ecoregion of Zapatosa [6]. As consequence, livestock and fishing activities in these municipalities exert great pressure on the ecosystem [6]. 

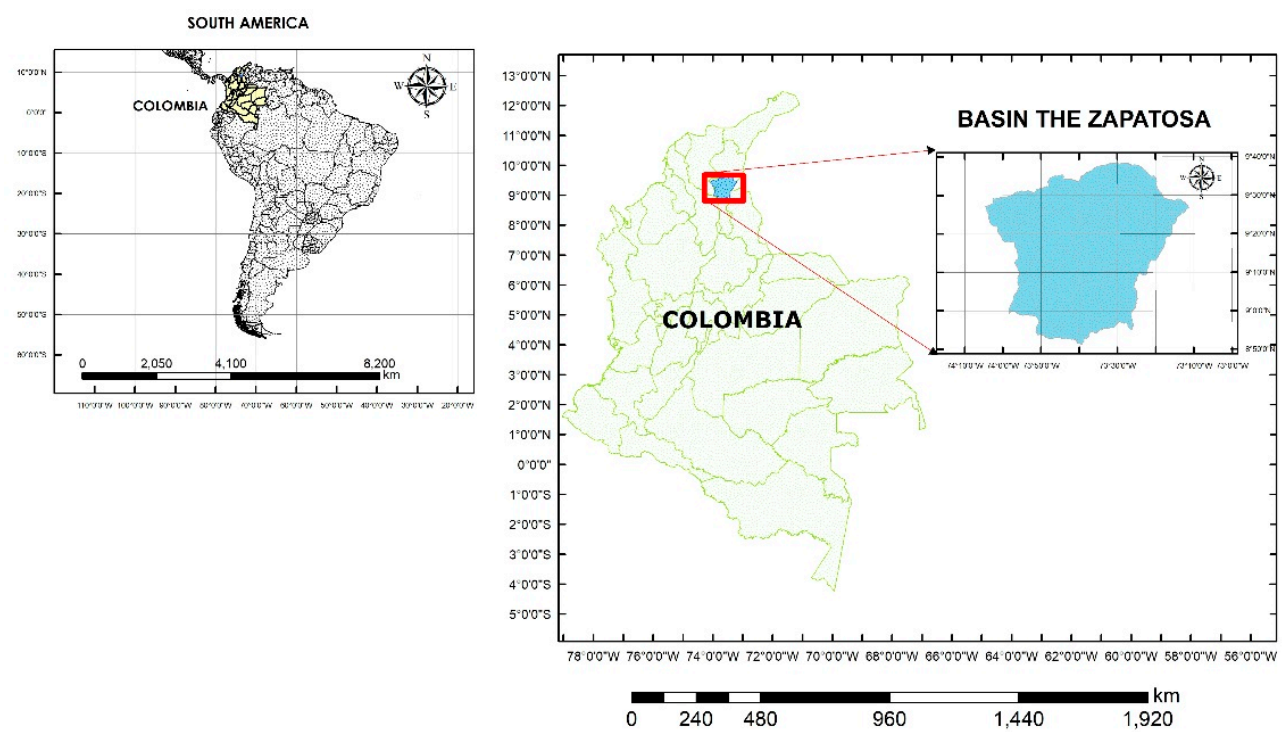

Figure 1. Location of the Zapatosa marsh.

\subsection{Information Colletion}

This work was framed in the project "Consolidation of the capacities of science, technology and innovation of the agricultural sector of the Department of the Cesar, aquaculture and fishing", and the main input for the elaboration of the model, were data obtained through the application of an aquaculture survey and artisanal fisheries of the Department of the Cesar during November and December 2018. The surveyed sample of the swamp's zone of influence included 334 fishermen out of a total population of 2533 fishermen in the area as reported, in 2018, by the National Aquaculture and Fisheries Authority (AUNAP) with a maximum error of $5 \%$. Trained interviewers face to face to local population of Zapatosa Marsh carried the survey. Questions were aimed to gather general information on the fisherman's (age, years of fishing experience, access to public services, etc), info on their family group, as well as data within different boundaries, as shown in Table 1.

Table 1. Survey boundaries.

\begin{tabular}{cc}
\hline Boundary & Description \\
\hline Productive boundary & $\begin{array}{c}\text { The main items are duration and number of fishing operations in the month, } \\
\text { catch in kilograms of fish per operation; costs of the fishing operation, } \\
\text { processing and added value, catch composition and fishing gear. }\end{array}$ \\
\hline Environmental boundary & $\begin{array}{c}\text { This module was designed to record information on the knowledge and } \\
\text { implementation of fisheries management measures issued by control bodies, } \\
\text { such as closed seasons and minimum catch sizes. }\end{array}$ \\
\hline Enterprise boundary & $\begin{array}{c}\text { Information was collected on the identification of the state of the associativity } \\
\text { in the artisanal fishing sector, the participation in associations or organizations, } \\
\text { the support of public or private entities for the promotion of the associativity } \\
\text { and the registration of information on the marketing activity of the products. }\end{array}$ \\
\hline
\end{tabular}

Source: Taken from Project Coordination and Management Team- aquaculture and fisheries technology development center (ECGP-CTA) (2017) for its initials in Spanish [22].

\subsection{Model Building}

The fishery model of the Zapatosa Marsh was based on the dynamics and interactions of a two stocks of renewable resources [11] and the FishBanks dynamics [23]. In this model the growth of the fish population is not only determined by the population growth rate, but also by the carrying capacity of the water body and the density of the fish. The catch of fish is defined by the maximum catch of each vessel and by the number of vessels that extract fish. The acquisition of new vessels depends on 
the capital available to invest and the fraction of that capital that will be allocated is that investment, in turn the utility of the fishing activity will determine that capital for investment, is in turn dependent on the fish caught and the price of fish, minus the cost of maintaining the vessel. Finally, abandoned vessels depend on the useful life of the vessels and a rate of elimination of these vessels.

In this paper, the software Vensim ${ }^{\circledR}$ PLE Plus version 6.3 (Ventana System, Inc. ${ }^{\circledR}$ ) was used to elaborate the qualitative and descriptive causal diagram and the quantitative model as Stock and flow diagram as described below.

The modeling technique used in this paper belongs to the system thinking (ST) and system dynamics approach (SD). ST and SD methods can be considered interdisciplinary sciences especially developed to enhance learning in complex systems [10]. ST and SD are grounded in the feedback control theories and draw on cognitive and social psychology, economics, and other social sciences to incorporate human dimensions and decision-making [10].

Qualitative steps of the systemic approach include the development of causal loop diagrams (CLD) through the identification of the main feedback loops among variables. The convention for drawing a CLD consists of a set of variables connected by arrows denoting causal influence with a given polarity. Polarity indicates how the dependent variables changes in relation to changes in the independent variables [10]. The loops are generated by connecting the variables with arrows. The direction of each arrow indicates causality and is characterized by polarity: a positive (+) or negative (-) sign corresponds to a positive or negative correlation between the connected variables, respectively. A " + " sign means that if one variable increases, so does the subsequent one, whereas a " - " sign means that if one variable increases, the subsequent one decreases. There are two kinds of loops that are studied on the basis of their characteristics: (1) Reinforcing ( $R$; from positive polarity), self-reinforcing loops (when multiplication of signs results equal to + ), implying that when these loops are the only ones operating in the system or are the dominant ones, the system grows exponentially; (2) Balancing (B; from negative polarity), self-correcting loops which counteract change (when multiplication of signs results equal to -) [24].

The causal diagram development started with the familiarization of the dynamic problem, to define precisely the aspects to be solved and to describe them in a precise and clear way [25]. It included the formulation of a clear hypothesis: The fisherman is embedded in a complex and dynamic environment, with factors in permanent interaction between the natural, economic and political system, which define the fishing system and its managerial alternatives. We proceeded identifying the variables constituting the system, then defining the interactions between the variables (negative on positive relationships) and mapping the loops of system connections. Later the generated loops are identified and their nature, if it is of reinforcement, it is because all the interactions are positive or it has a pair number of negative interactions, otherwise the loop will be of balance. The number of reinforcement and balance loops will define if the system is in balance, or if on the contrary it is an unbalanced system with a negative or positive tendency.

The quantitative model considers a diagram of an hydraulic metaphor which identifies Stocks (levels or integrals represented with a box) and flows (rates or first derivatives represented as inflows or outflows of the stocks) and constant variables (represented by variable names) which allow to simulate changes of variables over time [10].

The elaboration of the S\&F diagram is based on the already elaborated CLD diagram on which, Stock, flows and constant variables were identified. This diagram keeps the structure and constituting elements from the initial CLD, then was made more detailed by adding other auxiliary variables that allow specifying the quantitative aspects to run the simulation model.

\subsection{Parameterization and Calibration}

Calibration was done to run quantitative simulations and to evaluate if the model can reproduce the historical values and the pattern of behavior of the modeled variables. Calibration was performed using historical trends reported by official sources of variables included in the model, such as the 
population of the Department of Cesar and the total number of kilograms captured by fishermen in the swamp. As already mentioned, there is no constant monitoring of the fishing population of the Zapatosa marsh by institutions and for this reason the fish dynamics are not reliable over long time periods. However, the National Administrative Department of Statistics (DANE) has monitored the fish populations of the departments and municipalities of Colombia, thus data from the population of the Department of Cesar for the period between 2011 and 2016 [26]. Thus, due to the lack of information and uncertainty limitations, the calibration took into account this period in which the largest amount of information was available.

Other variable used for calibration was the total catch of the different fish species in the marsh gathered from the Colombian Fishing Statistical Service (SEPEC) of AUNAP, for 46 months from 2012 to 2016 [27]. The SEPEC considers 3 piers of fish deliveries to collect information whereas the only Zapatosa marsh included a total of 22 piers of deliveries (which accounts to $13.6 \%$ of the piers) even excluding the municipality of El Banco from Magdalena. For this reason, for the initial values of fish populations, fishers' population and variables such as the marsh area, were reduced to $13.6 \%$, in order to match the calibration data [27]. Due to the absence of data in literature for some variables, survey data were used for the simulations and the initial fish populations and fish catches per day were estimated according to the carrying capacity and the initial area of the marsh in the simulation. Initial simulation values are presented in Table 2 .

Table 2. Initial values used in the model calibration.

\begin{tabular}{|c|c|c|c|}
\hline Variable & Value & Unit & Source \\
\hline Population of the Department of Cesar & 979,015 & People & DANE, 2011 [26] \\
\hline Birth rate & 0.005 & $1 /$ month & DANE, 2018 [26] \\
\hline Deaths rate & 0.00341 & $1 /$ month & DANE, 2018 [26] \\
\hline Age to start fishing & 240 & Month & Survey \\
\hline Fishermen population & 344 & People & Gallardo, 2018 [3] \\
\hline Percentage of increased activity in months of subienda & 0.01 & $1 /$ month & Survey \\
\hline Percentage of lowering activity in months of bajanza & 0.01 & $1 /$ month & Survey \\
\hline Average monthly operating cost & 120,042 & Colombian pesos & Survey \\
\hline Average number of tasks per fisherman per month & 25 & Day & Survey \\
\hline Average catch per fisherman in a fishing day & 3.67 & $\mathrm{~kg}$ * day & SEPEC, 2018 [27] \\
\hline Population of other species & $11,950,000$ & Fish & Estimated \\
\hline Loading capacity & 726 & Fish & Lasso, et al., 2004 [28] \\
\hline Maximum fish reproduction rate & 0.1 & $1 /$ month & Landino, 2015 [29] \\
\hline Fish mortality rate & 0.0074 & $1 /$ month & Olaya, et al., 2014 [30] \\
\hline Percentage of fish for self-consumption & 0.083 & $1 /$ month & Survey \\
\hline Average weight of fish & 0.10002 & $\mathrm{~kg}$ & Acosta, $2019[31]$ \\
\hline Time of capture increase & 7 & Month & Estimated \\
\hline Capture percentage & 0.4 & $1 /$ month & Survey \\
\hline Price per kilogram of fish & 2297 & Colombian pesos & Survey \\
\hline Population of Prochilodus magdalenae & $12,123,000$ & Fish & Estimated \\
\hline Loading capacity of Prochilodus magdalenae & 763 & Fish & Lasso, et al., 2004 [28] \\
\hline Maximum fish reproduction rate of Prochilodus magdalenae & 0.05 & $1 /$ month & Landino, 2015 [29] \\
\hline Mortality rate of Prochilodus magdalenae & 0.0063 & $1 /$ month & Landino, 2015 [29] \\
\hline Percentage of Prochilodus magdalenae for self-consumption & 0.083 & $1 /$ month & Survey \\
\hline Average weight of Prochilodus magdalenae & 0.226 & $\mathrm{~kg}$ & Contreras, 2019 [32] \\
\hline Capture percentage of Prochilodus magdalenae & 0.42 & $1 /$ month & Survey \\
\hline Price per kilogram of Prochilodus magdalenae & 2461 & Colombian pesos & Survey \\
\hline Population of catfish & $5,817,900$ & Fish & Estimated \\
\hline Loading capacity of catfish & 145 & Fish & Lasso, et al., 2004 [28] \\
\hline Maximum fish reproduction rate of catfish & 0.05 & $1 /$ month & Landino, 2015 [29] \\
\hline Mortality rate of catfish & 0.002132 & $1 /$ month & Landino, 2015 [29] \\
\hline Percentage of catfish for self-consumption & 0.083 & $1 /$ month & Survey \\
\hline Average weight of catfish & 0.50653 & $\mathrm{~kg}$ & Arias, 2019 [33] \\
\hline Capture percentage of ccatfish & 0.18 & $1 /$ month & Survey \\
\hline Price per kilogram of catfish & 2141 & Colombian pesos & Survey \\
\hline
\end{tabular}

\subsection{Model Simulations and Scenarios}

According to the Vensim ${ }^{\circledR}$ settings, the model was simulated using a monthly time unit, a time horizon of 60 months (5 years), a time step of 1 and Euler integration method. The information collected in the survey resulted the basic simulation scenario (Survey data). Three other management scenarios 
of the swamp were simulated as shown in Table 3. For all simulations the same values of the swamp area and precipitation were used. Monthly values of precipitation from the Institute of Hydrology, Meteorology and Environmental Studies (IDEAM) were used. The initial values of model settings for all the scenarios were fixed as listed in in Table 2. For Scenario 2 and 3, an ecosystem services payment corresponding to an amount equal to minimum salary, per fisherman as determined by law, for the closure period was simulated. In Scenario 2 it was introduced monthly with the PULSE TRAIN function of Vensim ${ }^{\circledR}$ corresponding to the monthly salary they receive throughout the year for carrying out services, whereas in Scenario 3 it corresponded to a constant annual value. A comparison between simulated and actual data was made considering the pattern of behavior of simulated versus historical data and calculating a linear regressions of observed values vs. model predictions $[34,35]$.

Table 3. Alternative scenarios of fisheries management in the Zapatosa Marsh.

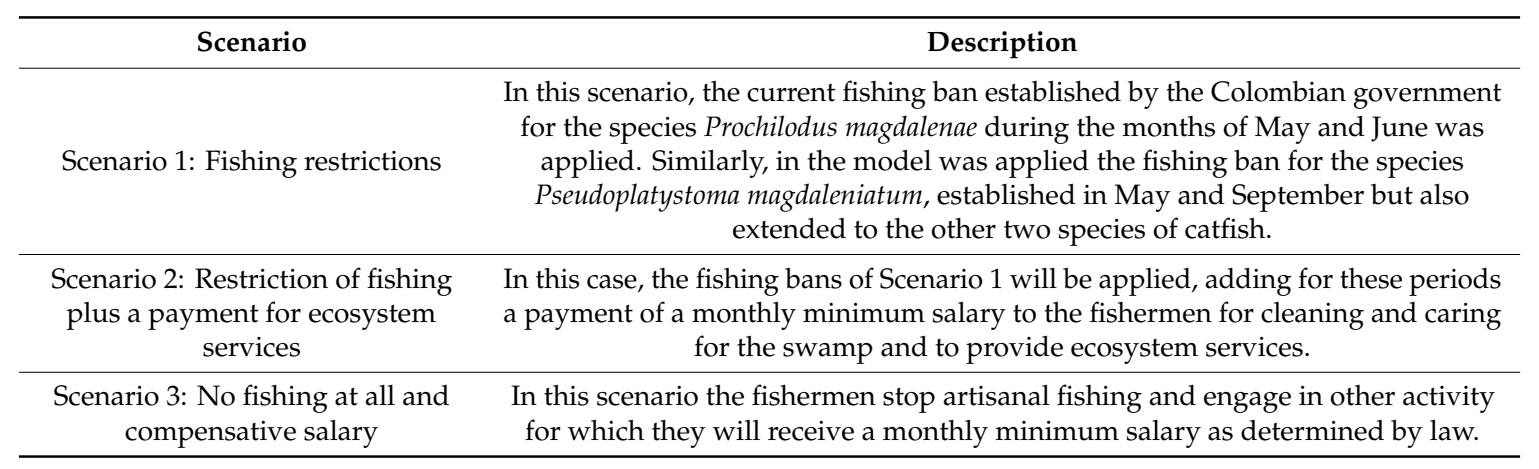

\section{Results and Discussion}

\subsection{Survey}

People surveyed from those engaged in artisanal fishing $(n=334)$ were $96 \%$ men and $4 \%$ women. They had an average age of 44 years, ranging from 20 years to 82 years old. Respondents who reported family income between 250 thousand and one million Colombian pesos were $67 \%$ whereas those with less than 250 thousand Colombian pesos were $33 \%$. Likewise, $97 \%$ of respondents say they have family expenses between 250 thousand pesos and one million pesos. About $99 \%$ percent of surveyed fishermen responded that they are permanently engaged in artisanal fishing, while $1 \%$ only seasonally. The average age at the beginning of the artisanal fishing activity was declared to be 20 years on average, with a minimum value of 5 years. Respondents stated that on average their fishing task takes 1 day, with a maximum value of 4 days. People also declared on average to carry out 25 tasks in a month. Particularly, $92 \%$ of the fish caught in a catch of each task is destined to market and $8 \%$ for self-consumption. On average the fish caught weights about $11.5 \pm 6.32$ (mean \pm me) kilograms with a minimum value of 2 kilograms and a maximum of 21 kilograms. The composition of this catch, in terms of species was shown in Figure 2. The importance of Prochilodus magdalenae (bocachico) is noteworthy, representing $42 \%$ of the catch, followed by Caquetaia kraussii (mojarra lora) with $13 \%$ and followed by Pimelodus blochii (nicuro), Piaractus brachypomus (cachama), Leporinus muyscorum (comelón) and Sorubim cuspicaudus (blanquillo), each representing $8 \%$ of the catch. Grouping all the species considered as catfish (Pimelodus blochii, Sorubim cuspicaudus, Pseudoplatystoma magdaleniatum) account for a total of $18 \%$ of the catch and the other species (excluding bocachico) complete a total of $40 \%$ of the catch in the marsh. These results are close to what SEPEC [27] reported in 2016 for the entire department, including river catches, where the bocachico was the most caught species, representing itself close to $65 \%$ of the total catch. The general average price according to those surveyed was 4624 Colombian pesos per $\mathrm{kg}$, but dividing it by species, the average price bocachico was 2461 pesos per $\mathrm{kg}$, ranging from 1000 to 4000 Colombian pesos; the average price of catfish was 2141 Colombian pesos per $\mathrm{kg}$ and the other species was 2297 until a maximum of 6000 Colombian pesos per $\mathrm{kg}$. 




Figure 2. Distribution of species of fishing catch according to the survey in the Zapatosa Marsh.

Several fisherman declared to no have a clear idea of the costs of fishing activity, but for 9 and 13 people the cost of fuel and labor were the most important, and equal to 34,222 Colombian pesos for fuel and 15,348 Colombian pesos for labor, respectively. The most part of people answered that the most important cost were the fishing gear, the cost of ice and the cost of the boat being equal to 21,226, 2755 and 368,178 Colombian pesos. Finally, 71 people responded on the cost of renting the boat, which averaged 29,866 pesos. In terms of the fishing regulations, $99 \%$ of the surveyed people declared to be aware of the fishing ban and relative dates but also to not respect them and continue to fish all the species in each period depending on their abundance.

\subsection{Causal Diagram}

The causal diagram developed for the artisanal fishing in the Zapatosa marsh was shown in Figure 3.

The reinforcing loop R1, and the balancing loop B1 represents the population dynamics of the Department of Cesar due to births and deaths. A lower population indicates less pressure on the marsh ecosystem. The reinforcement cycle R2 corresponds to the increase in the fish population due to the influence of a maximum reproduction rate and relative density. Relative density represents the carrying capacity since this population cannot grow indefinitely, because there are restrictions on space and food that regulate its growth. Similarly, in Figure 4 the reinforcement cycle R3 refers to the entry of fish into this population of the marsh, due to precipitation, which allows communication between the marsh and other nearby water bodies such as the Cesar and Magdalena rivers, other streams associated with these basins and small nearby marshes. 




Figure 3. Causal diagram of artisanal fisheries in the Zapatosa marsh. 




Figure 4. Loops of fish population, focus on reinforcing loop number 3.

Equilibrium and carrying capacity of the systems are regulated through different balancing loops. The balancing loop B3 corresponds to the decrease in the fish population, due to the effect of fishing from local inhabitants. The B5 represents the variation in catches acted by fishermen, after the rainy season, which generates additional pressure and decrease in the population following the fish abundances (Figure 5). On the other hand, the loop B4 corresponds to the effect of natural fish mortality, caused by other environmental circumstances and different predators, which in this model are not taken into account, but which has been estimated by different authors.

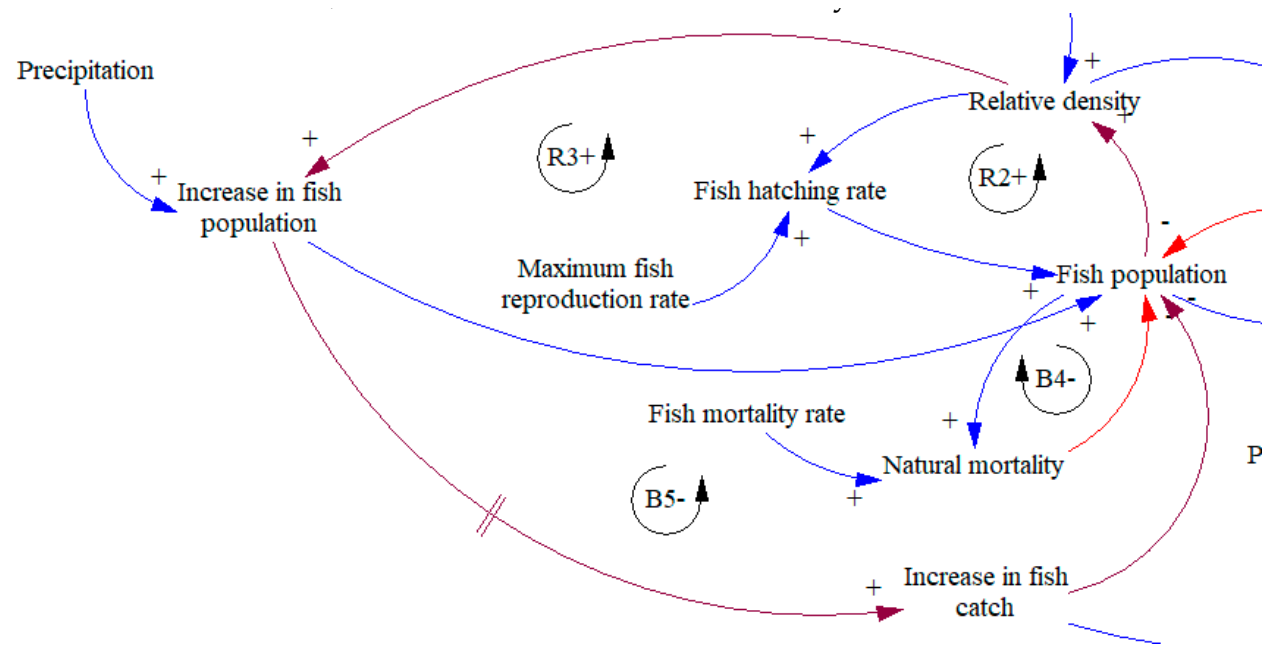

Figure 5. Loops of fish population focus on balancing loop number 5.

\subsection{Stock and Flow Diagrams}

In the Zapatosa marsh model, prey are represented by fish stocks and predators are artisanal fishermen population, a fraction of the population of the Department of Cesar. Taking into account the registered fishing population for 2018, it is estimated that fisherman corresponds to $0.24 \%$ of the population of the department. The stock and flow model follows the already presented CLD. Figures 6 and 7 show the levels, flows and variables of the population and the relative economic variables of the fishing activity. The fish populations were defined by their reproduction rate and the eventual entry of new individuals from other bodies of water following precipitation dynamics. The fish growth was limited by the relative fish density, which drives the maximum capacity of fish according to the aerial of the swamp. The fish population decreases by the natural mortality and by the catches, in turn 
affected by the average catch of each fisherman in a month, functions of the number of monthly tasks and the population of fishermen.

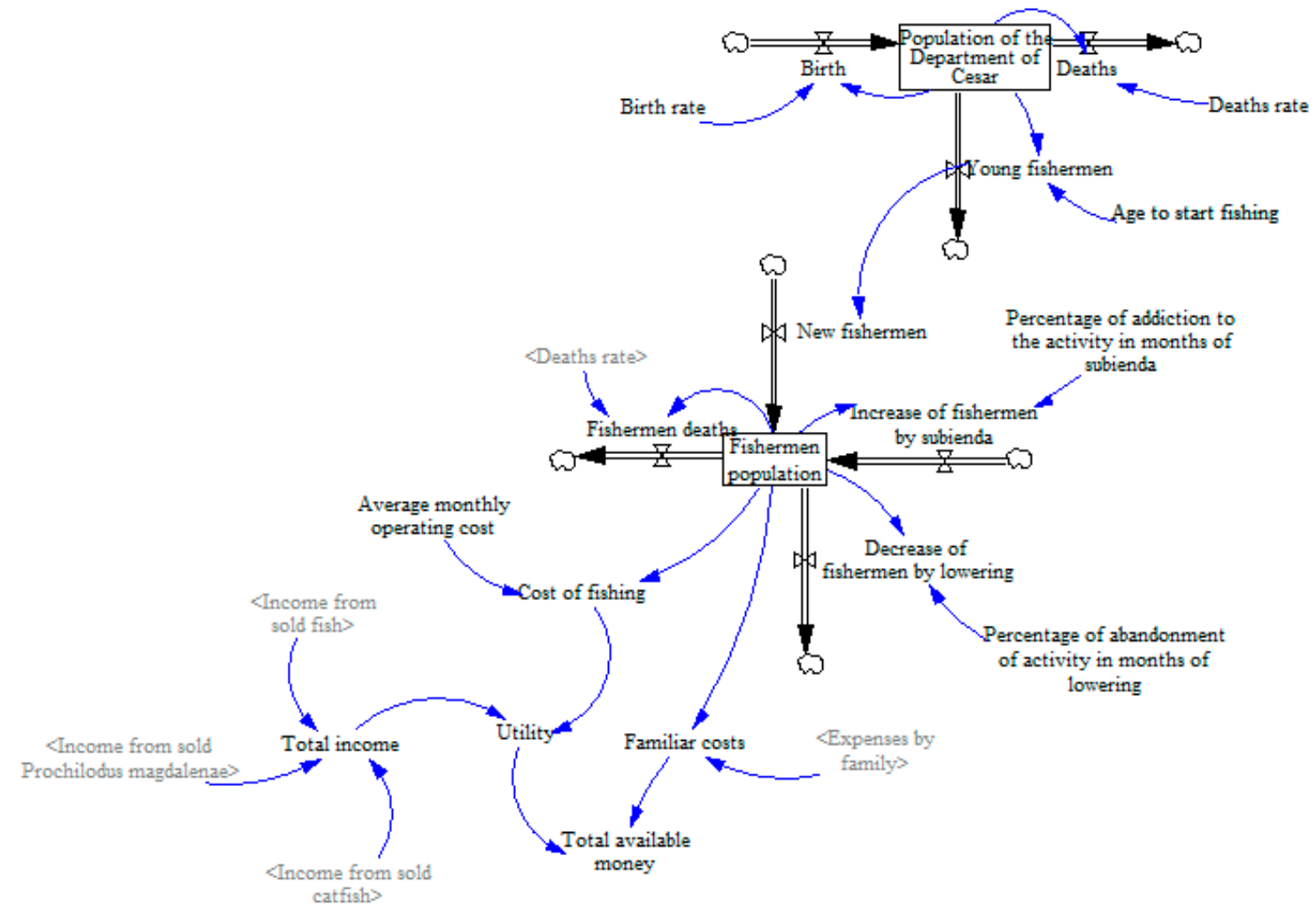

Figure 6. Stock and Flow diagram of human population in the Zapatosa marsh.

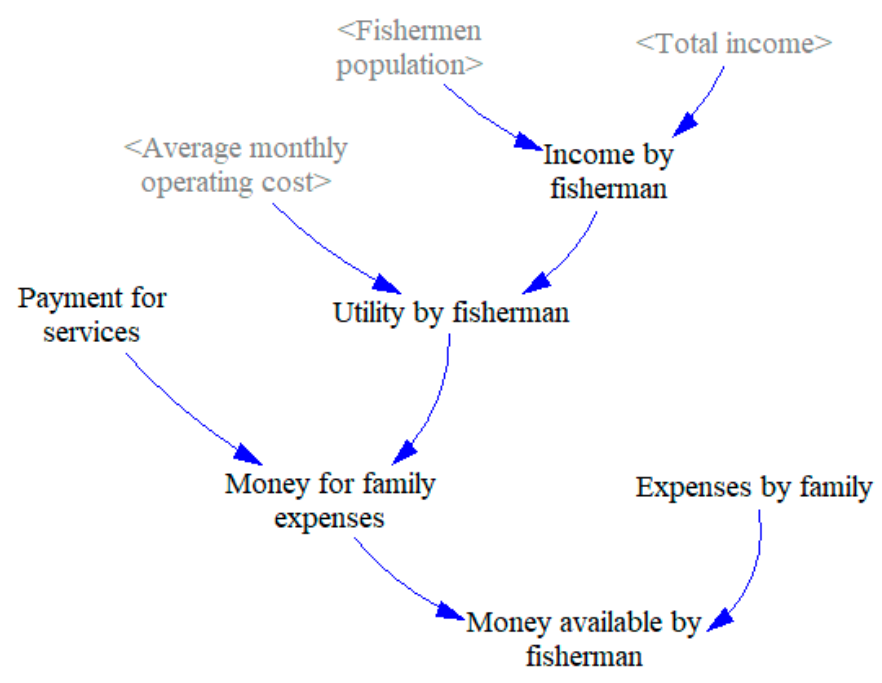

Figure 7. Modeled economic variables in the family economy.

The integrals of the stocks of the Cesar population and the fishermen population are shown in Equations (1) and (2). All the model equations are listed in Appendix A.

$$
\int(\text { Birth - Deaths - Young fishermen })
$$




$$
\begin{gathered}
\int \text { (New fishermen }+ \text { Increase of fishermen by "subienda" - Fishermen deaths } \\
\text { - Decrease of fishermen by lowering })
\end{gathered}
$$

Figure 8 shows the variables, flows and the level of the fish population, which was replicated 3 times in the model, to account for the diversity of the most important fish species. One population model represented the Prochilodus magdalenae, a second model the catfish species Pseudoplatystoma magdaleniatum, Pimelodus blochii and Sorubim cuspicaudus and the latter, the other species reported in the survey including Aequidens pulcher, Caquetaia kraussii, Curimata mivartii, Hoplias malabaricus, Leporinus muyscorum, Plagioscion surinamensis, Triportheus magdalenae and Piaractus brachypomus.

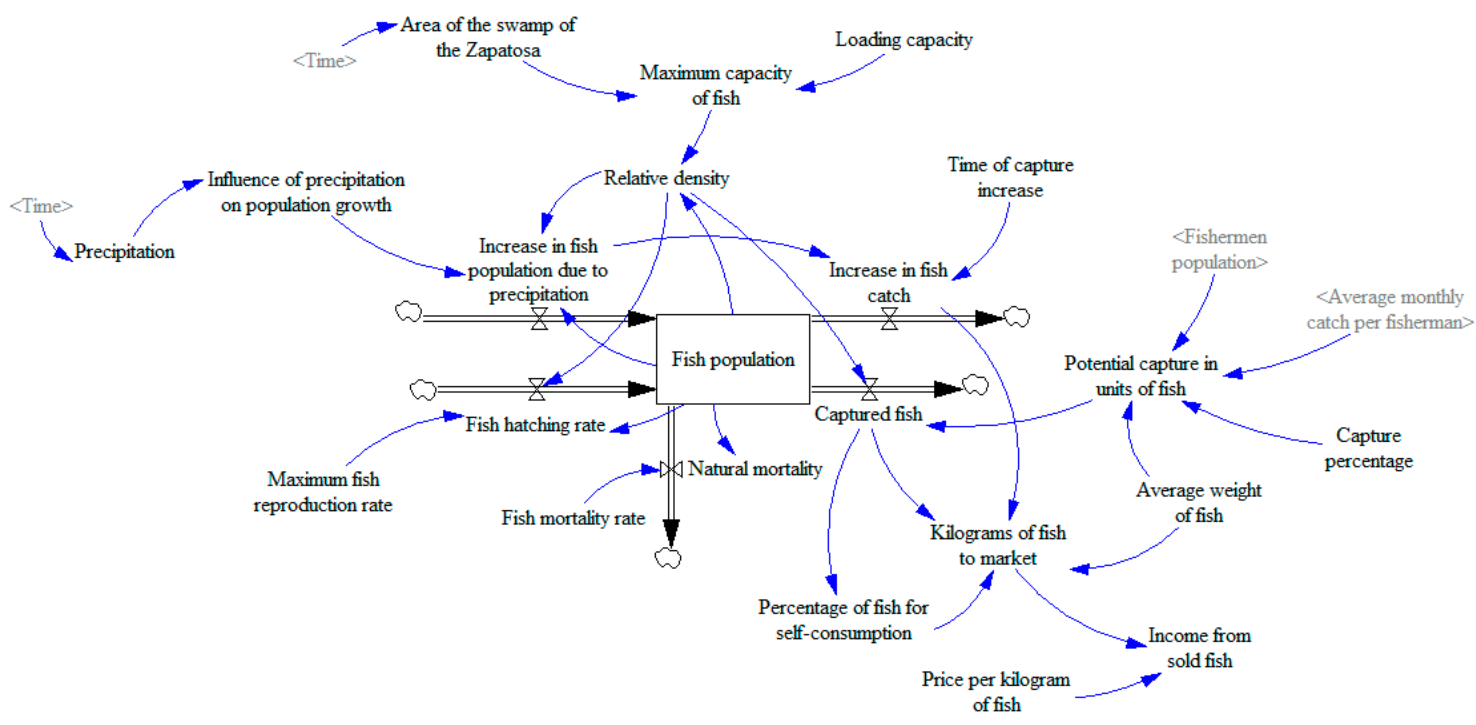

Figure 8. Stock and flow diagram of fish population.

The integral that applies to the three stocks of fish population in the model is in Equation (3). All the model equations are listed in Appendix A.

$$
\begin{gathered}
\int(\text { Increase in fish population due to precipitation }+ \text { Fish hatching rate } \\
- \text { Natural mortality - Captured fish - Increase in fish catch })
\end{gathered}
$$

\subsection{Parameterization and Calibration}

The comparison of the observed vs. predicted simulation of the human population of the Department of Cesar showed high precision with a $\mathrm{R}^{2}$ of 0.99 (data not shown). The regression of observed vs. predicted fish catches in kilograms of fish per month, showed a significant but low $\mathrm{R}^{2}$ (0.29; $p<0.05)$, but when the catches were considered seasonal, on a 3-month average, the regression showed a higher $R^{2}$ rises to 0.55 . Patterns of observed vs. predicted catches were shown in Figure 9. 




Figure 9. Model calibration for the variable of fish catch.

\subsection{Simulated Scenarios}

The model was run with settings for the survey data and the three formulated scenarios focusing the total kg of fish caught. In Figure 10, was shown the decrease in fishing for the Scenario 1 and 2, where the fishing restriction was applied. On the other hand, zero kg of fish catch was simulated for the Scenario 3. In the simulation of the survey data, it was seen that fish production is not constant during the year [6]. The decrease in the catch for the restriction periods reflected in the available money of fisherman's, which resulted in lowering family profit, calculated as the difference between incomes and the cost of fishing activity. Figure 11 showed that in all scenarios there were months with negative values of family profit, indicating that, in many cases, the fishing incomes are not enough to cover family expenses. It was already noticed by other authors [6] that the main reason for the economic stagnation of fishermen is their constant indebtedness, caused by fluctuations in the catch during the year and by the incomes which are not enough to cover their monthly expenses. Fluctuations in the catch were related to the rise and fall phenomena, which are dependent on climatic factors in turn causing increased nutrients in the wetland [2]. In addition, anthropic activities such as livestock and agriculture carried out in swamp areas of influence which also cause more nutrients to enter the marsh [6].

In Scenario 3, where incomes were assumed constant as provided by the government, fishermen could have money left over considering that family expenses are not constant and varied in the range of 250 and 1000 Colombian pesos or 250 and one million Colombian pesos, as detected in the survey. Scenario 1 showed the worst economic equilibrium for the local inhabitants, with negative values of family profit in the most part of the year. Otherwise in Scenario 2, the payment of a legal monthly minimum wage, facing the months of restrictions, generates a slight better situation in the same period. It might allow reaching higher levels of incomes than in the basic scenario of survey data, where all fish species are constantly caught during the year. On the other hand, restricted fish stocks showed a reduced recovery in Scenarios 1 and 2 and also continuing downwards. Scenario 3 showed the difference among the three stocks, without pressure from fishermen (Figure 12). 


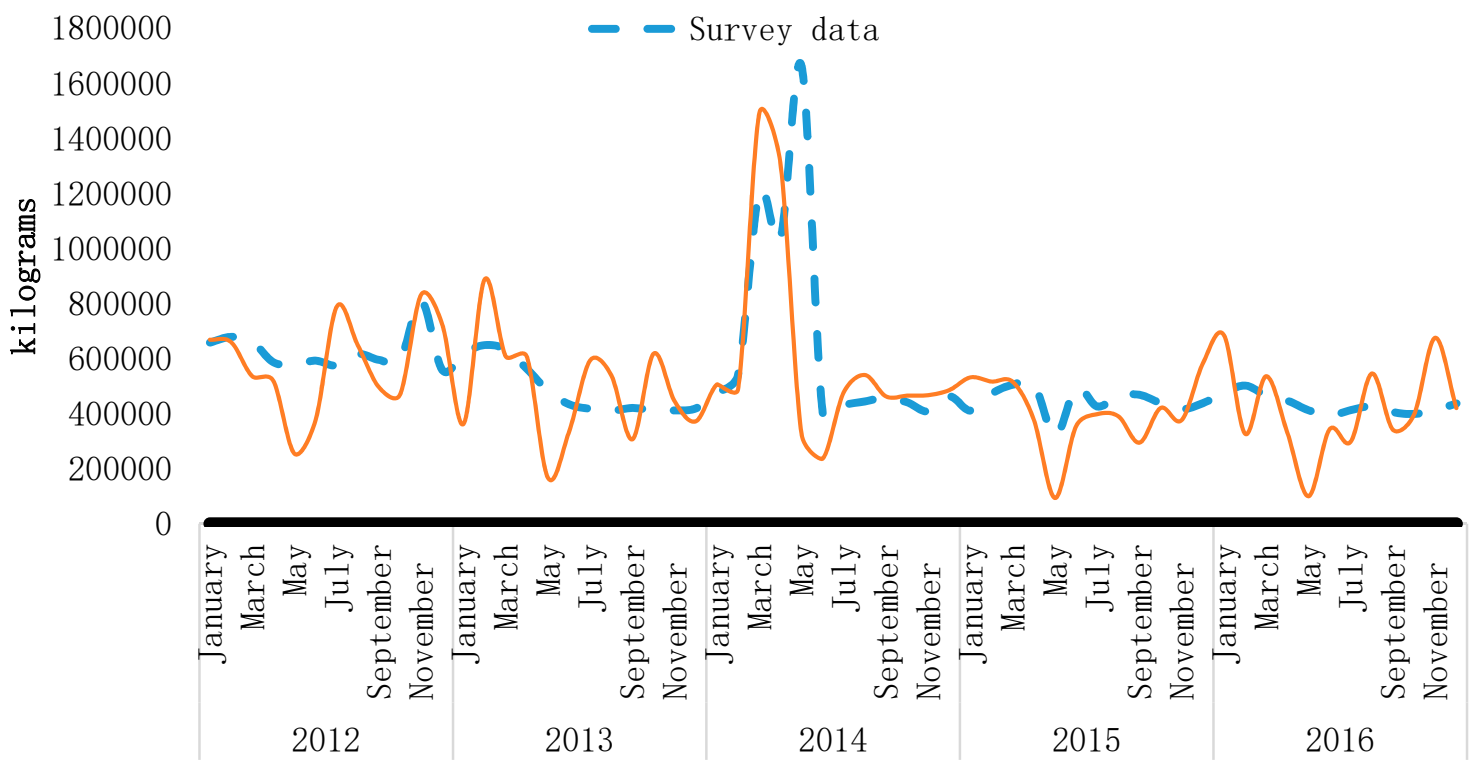

Figure 10. Model simulation of fish caught $(\mathrm{kg})$ in different scenarios. Survey data: continuous fishing of all species; Fishing restrictions and Restriction of fishing plus a salary: with fishing restriction in the months of May, June and September for two populations of fish; No fishing: Fishermen engaged in another activity.

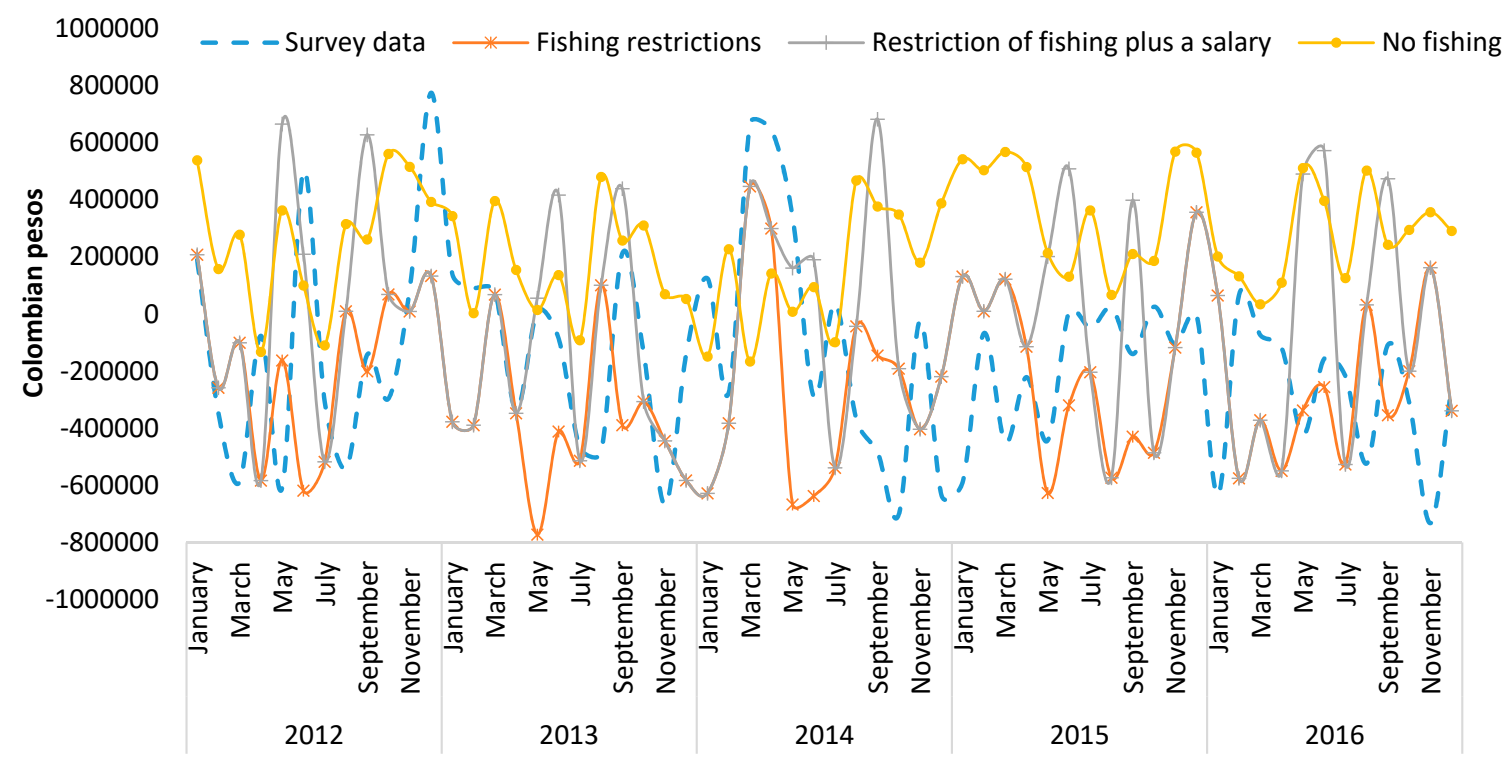

Figure 11. Money available by fisherman in different scenarios. Survey data: continuous fishing of all species; Fishing restrictions: with fishing restriction in the months of May, June and September for two populations of fish; Restriction of fishing plus a salary: with fishing restriction in the months of May, June and September for two populations of fish, with additional income corresponding to a minimum salary as determined by law; No fishing: Fishermen engaged in another activity. 

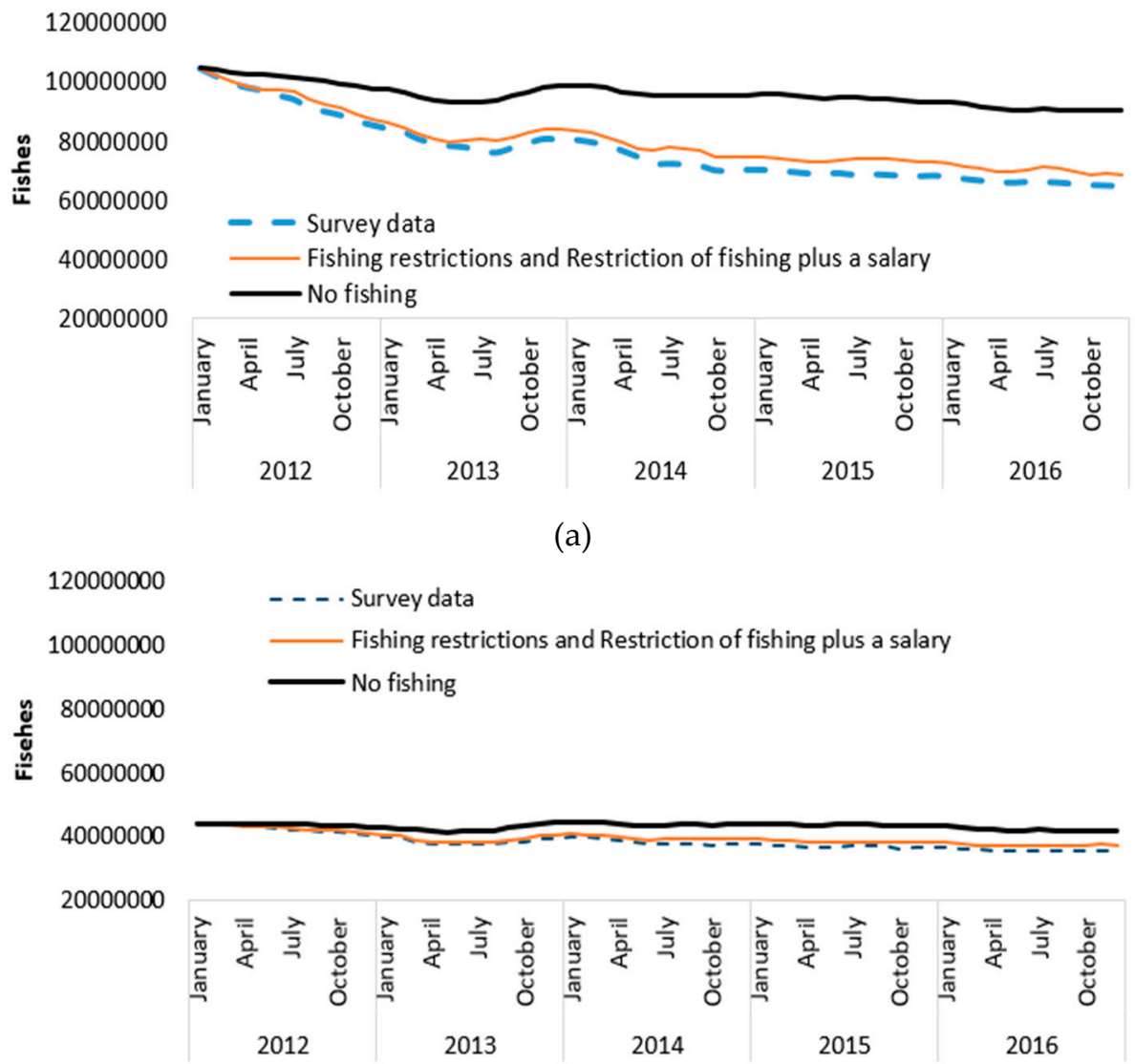

120000000

(b)

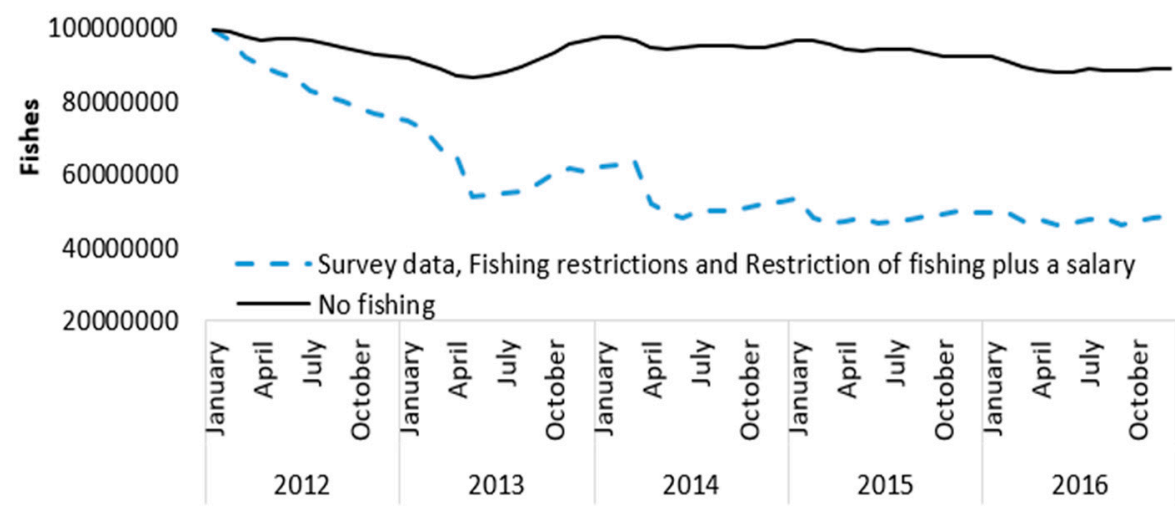

(c)

Figure 12. Fish populations in different scenarios. (a) Population of Prochilodus magdalenae; (b) Catfish population; (c) Population of other species not subjected to fishing restriction. Survey data: continuous fishing of all species; Fishing restrictions and Restriction of fishing plus a salary: with fishing restriction in the months of May, June and September for two populations of fish; No fishing: Fishermen engaged in another activity.

The model showed a similar behavior of fish and fishermen populations to what observed in other studies [16], and was also able to describe and seek the effect of the entry of fish into the swamp in rainy seasons and the subsequent fishing activity, with increase in catches and the gradual decline in the level of the swamp. The model was also able to simulate the economic difficulties experienced by the local population as already noticed by different authors [4-6]. For the fish stocks, the negative effect of 
extractive activity in the swamp is noticeable, the same phenomenon was also described in the fishery of the Tucuruí reservoir in Brazil [14]. Oppositely, the dynamics of the national economy, including the depreciation of the currency, the increase in inflation, the annual increase in the minimum salary and in the cost of living was not taken into account, but reasonably, it might have increased the pressure on the natural resources to overcome poverty. After these considerations and the model seems capable to summarize the weaknesses and benefits of the restriction seasons, which allowed in part to achieve a true recovery of fish populations as shown in Scenarios 1 and 2. Fish populations were not affected in Scenario 3, but this scenario is not easy to achieve in the short or medium term. In fact, fishing in the area is more than just a way to earn money, is a lifestyle and is part of cultural roots of the region. Therefore, the Scenario 2 is preferred since might generates short- and medium-term effective solutions, and improvements in people's income, and also a slight recovery of fish populations. Thus, this scenario could lead to unattended consequences if not supported by adequate measures of population information and education on the real benefits. Possible positive effects of people involvement wetland cleaning and care activities were not measured and should be also evaluated.

On the other hand, continuous fishing, without recovering periods for the fish populations, will bring to an excessive pressure to the resource and determine its diminutions every year with unsustainable trends in the long term. It will lead to catches that are commercially viable. It will also reduce, progressively, the catches and the abundance of fish after precipitations with total smaller volumes of fish catch and recoveries. Probably the best solution does not only include bans or restrictions on fishing without alternatives to the fishermen life. In Scenario 1, with only restrictions, was possible to highlight the negative effect on the family economy which would probably cause omission to the rules, in order to bring food and sustenance to families, similarly to the current situation already declared in the survey. Proposed scenarios could be considered valuable in the short and medium term, also considering the effort required by the regional government.

The model did not take into account additional anthropogenic activities that have an impact on the Zapatosa marsh and could affect positively or negatively the fishing system, such as cattle ranching, tourism, deforestation and pollution. In addition, the model did not take into account the phenomenon of the people migration from Venezuela to Colombia which has been happening since few years before the survey, and which is affecting the dynamics of the human population in the department of Cesar where a considerable number of Venezuelan migrants were received, as noticed also from the survey. Similarly, fishing was not measured in nearby bodies of water, such as the Magdalena River near the municipality of El Banco, which also might influence the swamp. The boundaries of this model were limited to the Zapatosa Marsh, which should be considered part of a broader watershed. The same seasonality of catches is affected by equilibrium of the entire watershed and not only by precipitation.

These omissions and assumptions might be considered as an oversimplification of the model and on the model output. A specific socioeconomic study to define alternative opportunities to fishing and to human exploitation of the area should be carried out in order to include these variables in the model and define new scenarios for the medium and long term.

The lack of official data for some variables did not allow a comparison with data reported by fishermen in the survey. Otherwise, the structure of the model represented the fishing system in an accurate way, in its majority of components and relevant elements or the described dynamics. A limit of the model is that it assumed that all fishermen made the same effort and fish catch in equal periods of time, that no fish are returned to the marsh and that no differences are made between the fishing gears used. In reality, these factors influence the individual performance and the efficiency of the fishing activity. However, the separation of fish populations into groups, allowed a differentiated analysis and allowed to test decisions and policies regarding the management of each group. Considering future application of the model it is necessary to run further analysis of restricted seasons and to understand the best choice for more efficient and significant recovery of fish populations. Feedback from the local population should also be considered about the feasibility of model predictions and applications and to avoid unattended behaviors. Simulations should be made in periods longer than 
10 or 20 years and considering restriction scenarios of different length (months to seasons every year), as occurs in the Orinoco basin in Colombia. These scenarios should take into account economic and labor alternatives for fishermen in the period when fishing is prohibited [6,36], which according to the development plans of the municipalities that have administrative jurisdiction over the wetland, are considered productive options such as agriculture, smallholder livestock and horticulture backyard systems for self-consumption and ecotourism in the area [6,37]. Further scenarios might consider productive activities such as aquaculture on a family scale in limited period of the year [36].

\section{Conclusions}

Following a survey on the fishing compartment of the artisanal fisheries in the Zapatosa marsh in the Department of Cesar (Colombia), a systems dynamics model was developed to test three alternative management scenarios of the fishing activity in the area. The scenarios evaluated the total catches of fish, the sustainability of fish population and the money available to fishermen in different condition of fishing restrictions aimed to dilute the human pressure on the natural ecosystem. In the limited boundaries of the model, which did not include other economic alternatives for population incomes, the best short and medium term alternative for the management of the marsh area resulted the combination of the restriction period with integration of a payment to the inhabitants for ecosystem services. It could allow to maintain the family incomes and to allow recovery of the fish population guarantying the fishing activity over time. However, other management options should be evaluated depending on the rural development priorities of the area. A total ban on long-term fishing could be better for the ecosystem but the population income should be replaced by other anthropogenic activities (such as ecosystem services, tourism, others) using also public money. Model expansion should consider also key elements that might impair the actual socioeconomic equilibrium, such as migrations from proximate countries or increases of husbandry and palm cultivation. In this limited structure the presented model provided a good basis to boost simulation scenarios for sustainable management of the Zapatosa Marsh.

Author Contributions: A.C.C.B.: Data collection, modeling, writing first draft, review, and editing. C.A.J.-C.: Conceptualization, writing, reviewing, and editing; R.A.M.: Writing reviewing and editing. A.S.A.: Conceptualization, modeling, writing, reviewing and editing. All authors have read and agree to the published version of the manuscript.

Funding: This research was funded by the project "Consolidation of the capacities of science, technology and innovation of the agricultural sector of the Department of the Cesar, aquaculture and fishing" within the framework of the special cooperation agreement No. 2015-03-0051 governorate of the department of Cesar and Universidad Nacional de Colombia.

Conflicts of Interest: The authors declare no conflicts of interest. 


\section{Appendix A}

Table A1. Equations of each variable in the model.

\begin{tabular}{|c|c|c|c|c|c|}
\hline Variable & Type & Equations & Variable & Type & Equations \\
\hline $\begin{array}{l}\text { Population of the } \\
\text { Departament of Cesar }\end{array}$ & Stock & INTEG (Birth-Deaths-Young fishermen) & $\begin{array}{l}\text { Population of other } \\
\text { species }\end{array}$ & Stock & $\begin{array}{l}\text { INTEG (Increase in fish population due to precipitation + Fish hatching } \\
\text { rate - Natural mortality - Captured fish - Increase in fish catch) }\end{array}$ \\
\hline Fishermen population & Stock & $\begin{array}{l}\text { INTEG (New fishermen+Increase of fishermen by } \\
\text { "subienda" - Fishermen deaths - Decrease of fishermen } \\
\text { by lowering) }\end{array}$ & $\begin{array}{l}\text { Population of Prochilodus } \\
\text { magdalenae }\end{array}$ & Stock & $\begin{array}{l}\text { INTEG (Increase in Prochilodus magdalenae opulation due to } \\
\text { precipitation + Prochilodus magdalenae catching rate - Natural mortality } \\
\text { of Prochilodus magdalenae - Captured Prochilodus magdalenae - Increase } \\
\text { in Prochilodus magdalenae catch }\end{array}$ \\
\hline Birth & Flow & Population of the demartament of Cesar * Birth rate & Population of catfish & Stock & $\begin{array}{l}\text { INTEG (Increase in catfish population due to precipitation + Catfish } \\
\text { hatching rate-Natural mortality of catfish-Captured catfish-Increase in } \\
\text { catfish catch) }\end{array}$ \\
\hline Deaths & Flow & Population of the demartament of Cesar * Deaths rate & $\begin{array}{l}\text { Average monthly catch } \\
\text { per fisherman }\end{array}$ & Auxiliary & $\begin{array}{l}\text { Average catch per task per fisherman * Average number of operations } \\
\text { per fisherman per month }\end{array}$ \\
\hline Young fishermen & Flow & $\begin{array}{l}\text { (Population of the demartament of Cesar *0.0024)/ Age } \\
\text { to start fishing }\end{array}$ & $\begin{array}{l}\text { Potential capture in units } \\
\text { of fish }\end{array}$ & Auxiliary & $\begin{array}{l}\text { ((Average monthly catch per fisherman * Capture percentage)/Average } \\
\text { weight of fish) * Fishermen population }\end{array}$ \\
\hline $\begin{array}{l}\text { Increase of fishermen by } \\
\text { subienda }\end{array}$ & Flow & $\begin{array}{l}\text { PULSE TRAIN }(11,3,12,36)^{*} \text { Fishermen population * } \\
\text { Percentage of addiction to the activity in months of } \\
\text { subienda }\end{array}$ & Increase in fish catch & Flow & $\begin{array}{l}\text { DELAY FIXED (Increase in fish population due to precipitation, Time } \\
\text { of capture increase, } 0 \text { ) }\end{array}$ \\
\hline $\begin{array}{l}\text { Decrease of fishermen } \\
\text { by lowering }\end{array}$ & Flow & $\begin{array}{l}\text { PULSE TRAIN }(3,4,12,36)^{*} \text { Fishermen population * } \\
\text { Percentage of abandonment of activity in months of } \\
\text { lowering }\end{array}$ & Maximum capacity of fish & Auxiliary & Loading capacity * Area of the swamp of the Zapatosa \\
\hline Familiar costs & Auxiliary & Expenses by family * Fishermen population & Relative density & Auxiliary & Population of other species /Maximum capacity of fish \\
\hline Cost of fishing & Auxiliary & Fishermen population * Average monthly operating cost & Fish hatching rate & Flow & $\begin{array}{l}\text { Maximum fish reproduction rate * Population of other species * }(1- \\
\text { Relative density) }\end{array}$ \\
\hline Total income & Auxiliary & $\begin{array}{l}\text { Income from sold catfish+Income from sold Prochilodus } \\
\text { magdalenae+Income from sold fish }\end{array}$ & $\begin{array}{l}\text { Increase in fish population } \\
\text { due to precipitation }\end{array}$ & Flow & $\begin{array}{l}\text { Influence of precipitation on population growth * Population of other } \\
\text { species * (1 - Relative density) }\end{array}$ \\
\hline Utility & Auxiliary & Total income-Cost of fishing & Natural mortality & Flow & Population of other species * Fish mortality rate \\
\hline Total available money & Auxiliary & Utility-Familiar costs & Captured fish & Flow & Potential capture in units of fish * Relative density \\
\hline Income by fisherman & Auxiliary & Total income / Fishermen population & $\begin{array}{l}\text { Kilograms of fish to } \\
\text { market }\end{array}$ & Auxiliary & $\begin{array}{l}\text { ((Captured fish+Increase in fish catch) - "Percentage of fish for } \\
\text { self-consumption") * Average weight of fish }\end{array}$ \\
\hline Utility by fisherman & Auxiliary & Income by fisherman-Average monthly operating cost & Income from sold fish & Auxiliary & Kilograms of fish to market ${ }^{*}$ Price per kilogram of fish \\
\hline $\begin{array}{l}\text { Money available by } \\
\text { fisherman }\end{array}$ & Auxiliary & Money for family expenses-Expenses by family & Price per kilogram of fish & Auxiliary & RANDOM NORMAL ( 400, 6000, 2297.7, 821.4, 0) \\
\hline Expenses by family & Auxiliary & RANDOM UNIFORM $(250,000,1,000,000,0)$ & $\begin{array}{l}\text { Percentage of fish for } \\
\text { self-consumption }\end{array}$ & Auxiliary & Captured fish * 0.083 \\
\hline $\begin{array}{l}\text { Potential capture in } \\
\text { units of Prochilodus } \\
\text { magdalenae }\end{array}$ & Auxiliary & $\begin{array}{l}\text { ((Average monthly catch per fisherman * Prochilodus } \\
\text { magdalenae catch percentage)/Average weight of } \\
\text { Prochilodus magdalenae })^{*} \text { Fishermen population }\end{array}$ & Average weight of fish & Auxiliary & RANDOM NORMAL $(0.006,0.95,0.10002,0.0403,0)$ \\
\hline
\end{tabular}


Table A1. Cont.

\begin{tabular}{|c|c|c|c|c|c|}
\hline Variable & Type & Equations & Variable & Type & Equations \\
\hline $\begin{array}{l}\text { Increase in Prochilodus } \\
\text { magdalenae catch }\end{array}$ & Flow & $\begin{array}{l}\text { DELAY FIXED (Increase in fish population due to } \\
\text { precipitation, Time of capture increase, } 0 \text { ) }\end{array}$ & $\begin{array}{l}\text { Potential capture in units } \\
\text { of catfish }\end{array}$ & Auxiliary & $\begin{array}{l}\text { ((Average monthly catch per fisherman * Catfish catch } \\
\text { percentage)/Average weight of catfish }) * \text { Fishermen population }\end{array}$ \\
\hline $\begin{array}{l}\text { Maximum Prochilodus } \\
\text { magdalenae capacity }\end{array}$ & Auxiliary & $\begin{array}{l}\text { Loading capacity of Prochilodus magdalenae* Area of the } \\
\text { swamp of the Zapatosa }\end{array}$ & Increase in catfish catch & Flow & $\begin{array}{l}\text { DELAY FIXED (Increase in fish population due to precipitation, Time } \\
\text { of capture increase, } 0 \text { ) }\end{array}$ \\
\hline $\begin{array}{l}\text { Prochilodus magdalenae } \\
\text { Relative density }\end{array}$ & Auxiliary & $\begin{array}{l}\text { Population of Prochilodus magdalenae / Maximum } \\
\text { Prochilodus magdalenae capacity }\end{array}$ & Maximum catfish capacity & Auxiliary & Loading capacity of catfish * Area of the swamp of the Zapatosa \\
\hline $\begin{array}{l}\text { Prochilodus magdalenae } \\
\text { hatching rate }\end{array}$ & Flow & $\begin{array}{l}\text { Maximun fish reproduction rate of Prochilodus } \\
\text { magdalenae * Population of Prochilodus magdalenae * }(1- \\
\text { Prochilodus magdalenae Relative density ) }\end{array}$ & Catfish relative density & Auxiliary & Population of catfish / Maximum catfish capacity \\
\hline $\begin{array}{l}\text { Increase in Prochilodus } \\
\text { magdalenae population } \\
\text { due to precipitation }\end{array}$ & Flow & $\begin{array}{l}\text { Influence of precipitation on population growth * } \\
\text { Population of Prochilodus magdalenae * (1-Prochilodus } \\
\text { magdalenae Relative density ) }\end{array}$ & Catfish hatching rate & Flow & $\begin{array}{l}\text { Maximun fish reproduction rate of catfish * Population of catfish * }(1- \\
\text { catfish relative density ) }\end{array}$ \\
\hline $\begin{array}{l}\text { Natural mortality of } \\
\text { Prochilodus magdalenae }\end{array}$ & Flow & $\begin{array}{l}\text { Population of Prochilodus magdalenae* Mortality rate of } \\
\text { Prochilodus magdalenae }\end{array}$ & $\begin{array}{l}\text { Increase in catfish } \\
\text { population due to } \\
\text { precipitation }\end{array}$ & Flow & $\begin{array}{l}\text { Influence of precipitation on population growth * Population of catfish } \\
*(1-\text { catfish relative density })\end{array}$ \\
\hline $\begin{array}{l}\text { Captured Prochilodus } \\
\text { magdalenae }\end{array}$ & Flow & $\begin{array}{l}\text { Potential capture in units of Prochilodus magdalenae * } \\
\text { Prochilodus magdalenae Relative density }\end{array}$ & $\begin{array}{l}\text { Natural mortality of } \\
\text { catfish }\end{array}$ & Flow & Population of catfish * Mortality rate of catfish \\
\hline $\begin{array}{l}\text { Kilograms of Prochilodus } \\
\text { magdalenae to market }\end{array}$ & Auxiliary & $\begin{array}{l}\text { ((Captured Prochilodus magdalenae + Increase in } \\
\text { Prochilodus magdalenae catch) - "Percentage of } \\
\text { Prochilodus magdalenae for self-consumption") * Avarage } \\
\text { weight of Prochilodus magdalenae }\end{array}$ & Captured catfish & Flow & Potential capture in units of catfish * catfish relative density \\
\hline $\begin{array}{l}\text { Income from sold } \\
\text { Prochilodus magdalenae }\end{array}$ & Auxiliary & $\begin{array}{l}\text { Kilograms of Prochilodus magdalenae to market * Price per } \\
\text { kilogram of Prochilodus magdalenae }\end{array}$ & $\begin{array}{l}\text { Kilograms of catfish to } \\
\text { market }\end{array}$ & Auxiliary & $\begin{array}{l}\text { ((Captured catfish+Increase in catfish catch) - "Percentage of catfish } \\
\text { for self-consumption") * Avarage weight of catfish }\end{array}$ \\
\hline $\begin{array}{l}\text { Price per kilogram of } \\
\text { Prochilodus magdalenae }\end{array}$ & Auxiliary & RANDOM NORMAL $(1000,4000,2461.6,585.1,0)$ & Income from sold catfish & Auxiliary & Kilograms of catfish to market * Price per kilogram of catfish \\
\hline $\begin{array}{l}\text { Percentage of } \\
\text { Prochilodus magdalenae } \\
\text { for self-consumption }\end{array}$ & Auxiliary & Captured Prochilodus magdalenae $* 0.083$ & $\begin{array}{l}\text { Price per kilogram of } \\
\text { catfish }\end{array}$ & Auxiliary & RANDOM NORMAL $(800,4000,2141.25,730.5,0)$ \\
\hline \multirow[t]{2}{*}{$\begin{array}{l}\text { Average weight of } \\
\text { Prochilodus magdalenae }\end{array}$} & Auxiliary & RANDOM NORMAL $(0.119,0.558,0.226,0.0741,0)$ & $\begin{array}{l}\text { Percentage of catfish for } \\
\text { self-consumption }\end{array}$ & Auxiliary & Captured catfish $* 0.083$ \\
\hline & & & Average weight of catfish & Auxiliary & RANDOM NORMAL $(0.136,2.25,0.50653,0.2965,0)$ \\
\hline
\end{tabular}




\section{References}

1. Incoder. Pesca y Acuicultura Colombia 2006; Incoder: Bogotá, Colombia, 2007; p. 55.

2. Corporación Autónoma Regional del Sur de Bolívar; CSB, (Coordinación General). Plan de Manejo Integral de los Humedales, Subregión de la Depresión Momposina y Cuenca del Río Sinú; Ministerio del Medio Ambiente, CBS, Corpomojana, Corantioquia, Corpomag y CVS, Bolívar: Magangué, Colombia, 2002.

3. Gallardo, N. Auntoridad Nacional de Acuicultura y Pesca (AUNAP); Comunicación Personal: Barranquilla, Colombia, 2018.

4. Rangel, J. Informe Final de Actividades. Estudio de Inventario de Fauna, Flora, Descripción Biofísica y Socioeconómica y Linea de Base Ambiental Ciénaga de Zapatosa; Corpocesar-Universidad Nacional de Colombia: Bogotá, Colombia, 2007.

5. Alcaldía de Chimichagua. Plan de Desarrollo Municipal 2006-2007; Un territorio en marcha, Alcaldía de Chimichagua: Chimichagua, Colombia, 2006; p. 38.

6. Viloria-de-la-Hoz, J. Economía Extractiva y Pobreza en la Ciénaga de Zapatosa; No. 103.; Banco de la República-Centro de Estudios Económicos Regionales (CEER): Cartagena de indias, Colombia, 2008; pp. 5-16.

7. Paz, A. Complejo Cenagoso de Zapatosa: Nuevo Sitio Ramsar de Colombia. 2008. Available online: https://es.mongabay.com/2018/04/zapatosa-nueva-area-protegida-colombia/ (accessed on 29 April 2019).

8. Morelo, L. Caracterizaciones Biológicas. Informe Final-Producto Doce-Requerido Para el Tercer Desembolso del Convenio de Cooperación no. 15-12-067-002 Entre el Instituto de Investigación de Recursos Biológicos Alexander Von Humboldt y la Fundación Fluvial. 2015. Available online: http://repository.humboldt.org.co/ bitstream/handle/20.500.11761/9345/11Fluvialia_Cienaga_Zapatosa.pdf?sequence=1\&isAllowed=y (accessed on 8 April 2019).

9. Senge, P. The Fifth Discipline; DOUBLEDAY: New York, NY, USA, 1990.

10. Sterman, J.D. Business Dynamics: Systems Thinking and Modeling for a Complex World, 6nd ed.; Jeffrey, J., Shelsfud, J.J., Eds.; McGraw-Hill: New York, NY, USA, 2000.

11. Meadows, D. Chapter One: The Basics. Thinking in Systems; Chelsea Green: White River Junction, VT, USA, 2008.

12. McRoberts, K.C. Structure and impact of cattle manure trade in crop-livestock systems of Vietnam. Renew. Agric. Food Syst. 2018, 33, 86-101. [CrossRef]

13. Dudley, R.G. A basis for understanding fishery management dynamics. Syst. Dyn. Rev. J. Syst. Dyn. Soc. 2008, 24, 1-29. [CrossRef]

14. Camargo, S.A.F.D.; Petrere, M., Jr. Análise de risco aplicada ao manejo precaucionário das pescarias artesanais na região do reservatório da UHE-Tucuruí (Pará, Brasil). Acta Amazonica 2004, 34, 473-485. [CrossRef]

15. Fadul, V.O. Modelo Dinámico del Sistema Sociobiológico Ciénaga Grande de Santa Marta. Master's Thesis, Universidad de los Andes, Bogotá, Colombia, 2008.

16. Garrity, E.J. System Dynamics Modeling of individual transferable quota fisheries and suggestions for rebuilding stocks. Sustainability 2011, 3, 184-215. [CrossRef]

17. Martins, J.H.; Camanho, A.S.; Oliveira, M.M.; Gaspar, M.B. A system dynamics model to support the management of artisanal dredge fisheries in the south coast of Portugal. Int. Trans. Oper. Res. 2015, 22, 611-634. [CrossRef]

18. Cenek, M.; Franklin, M.; Trammell, E.J.; Dahl, S. How will the Kenai fisheries respond to changing environmental conditions: Scenario based studies of coupled socio-ecological systems dynamics using an agent-based model. In Proceedings of the OCEANS-Anchorage, Anchorage, AK, USA, 18-21 September 2017; pp. 1-8.

19. Storch, L.S.; Glaser, S.M.; Ye, H.; Rosenberg, A.A. Stock assessment and end-to-end ecosystem models alter dynamics of fisheries data. PLoS ONE 2017, 2, e0171644. [CrossRef] [PubMed]

20. Inomata, S.O.; Gonzalez, A.M.G.O.; Román, R.M.S.; de Souza, L.A.; de Carvalho Freitas, C.E. Sustainability of small-scale fisheries in the middle Negro River (Amazonas-Brazil): A model with operational and biological variables. Ecol. Model. 2018, 368, 312-320. [CrossRef]

21. Comisión Regional de Competitividad (CRC). Perfil de Competitividad del Departamento del Cesar-Programa de Asistencia Técnica a la CRC; CRC: Valledupar, Colombia, 2011. 
22. ECGP-CTA, ENCUESTA ACUÍCOLA Y PESQUERA ARTESANAL DEL DEPARTAMENTO DEL CESAR; Convenio Especial de Cooperación no. 2015-03-0051; Gobernación del Departamento del Cesar y Universidad Nacional de Colombia: Bogotá, Colombia, 2017.

23. Meadows, D.; Fiddaman, T.; Shannon, D. FishBanks Ltd: Institute for Policy and Social Science Research; Hood House, University of New Hampshire: Durham, UK, 1898.

24. Armendariz, V.; Armenia, S.; Atzori, A.S. Systemic analysis of Food Supply and Distribution Systems (FSDS) in City-Region systems. Agriculture 2016, 6, 65. [CrossRef]

25. Aracil, J.; Gordillo, F. Dinámica de Sistemas; Alianza Editorial: Madrid, Spain, 1995; pp. 10-12.

26. Departamento Administrativo Nacional de Estadística (DANE). Proyecciones de Poblaciones Departamentales Por Área: Censo Nacional de Población y Vivienda -CNPV- 2018. Available online: http://www.dane.gov.co/ (accessed on 10 October 2019).

27. SEPEC. Informes Gráficos y Tabulares. Available online: http://sepec.aunap.gov.co/ (accessed on 7 March 2019).

28. Lasso, C.; Lasso-Alcalá, O.; Pombo, C.; Smith, Y.M. Composición, abundancia y biomasa de la ictiofauna béntica del delta del río Orinoco (caño y boca de Pedernales, Manamo, Manamito, boca de Bagre) y golfo de Paria (río Guanipa, caño Venado). Bull. Biol. Assess. 2004, 37, 85-102.

29. Ladino Martínez, L.M. Modelos de Dinámicas Migratorias con Factores de Reclutamiento, Depredación y Captura. Ph.D. Thesis, Universidad de Castilla la Mancha, Ciudad Real, Spain, 2012.

30. Olaya-Nieto, C.W.; Ubarnes-Coronado, G.M.; Ensuncho-Morales, J.E. Crecimiento y mortalidad de mojarra amarilla caquetaia kraussii en la ciénaga Grande de Lorica, Colombia. Rev. Logos Cienc. Tecnol. 2014, 5, 202-212. [CrossRef]

31. Acosta Murgas, L.A. Impacto Ecológico de la Contaminación Orgánica en la Dinámica de la Comunidad Íctica en la Ciénaga de Zapatosa. Master's Thesis, Universidad Nacional de Colombia, Palmira, Colombia, 2019.

32. Contreras Almanza, I.A.E. Influencia de Condiciones Antrópicas Sobre la Reproducción en Hembras de Prochilodus Magdalenae (Steindachner, 1879) en el Complejo Cenagoso de la Zapatosa. Master's Thesis, Universidad Nacional de Colombia, Palmira, Colombia, 2019.

33. Arias Vanegas, E.J. Variación Espacio-Temporal en la Concentración de Mercurio del Bagre Rayado Pseudoplatystoma Magdaleniatum en la Ciénaga de Zapatosa. Master's Thesis, Universidad Nacional de Colombia, Palmira, Colombia, 2019.

34. Tedeschi, L.; Nicholson, C.; Rich, E. Using system dynamics modelling approach to develop management tools for animal production with emphasis on small ruminants. Small Rumin. Res. 2011, 98, 102-110. [CrossRef]

35. Turner, B.L.; Menendez, H.; Gates, R.; Tedeschi, L.O.; Atzori, A.S. System dynamics modeling for agricultural \& natural resource management issues: Review of some past cases and forecasting future roles. Resouces 2016, 5, 1-24.

36. Rangel, J.O.; Peña, H.A. Plan de Manejo Ambiental del Complejo Cenagoso de Zapatosa; Universidad Nacional de Colombia: Valledupar, Colombia, 2007.

37. Molina, R.; Atzori, A.S.; Campos, R.; Sanchez, H. Using system thinking to study sustainability of Colombian dairy system. Bus. Syst. Rev. 2014, 3, 123-141.

(C) 2020 by the authors. Licensee MDPI, Basel, Switzerland. This article is an open access article distributed under the terms and conditions of the Creative Commons Attribution (CC BY) license (http://creativecommons.org/licenses/by/4.0/). 